\title{
PENGATURAN MENGENAI HARGA SAHAM WAJAR SEBAGAI BENTUK PERLINDUNGAN HUKUM TERHADAP PEMEGANG SAHAM PUBLIK DALAM MERGER BANK YANG BERBENTUK PERSEROAN TERBUKA
}

Oleh :

Pande Yogantara S.

\author{
Mahasiswa Magister Ilmu Hukum Unud
}

\begin{abstract}
Banking crisis that occurred in 1997 and the issuance of Bank Indonesia regulations Number 8/16/PBI/2006 Regarding Single Presence on Indonesian Banking, led to a merger in the banking industry. Merger action is a legal act, not only causes economic and financial consequences but also the juridical consequences.

The consequences of the merger to be seen is the impact on the public shareholders especially in the of bank in form public company. In the event of a merger, position of public shareholders is very weak in regard to corporate decision-making (the company). If the views of the ownership of shares, public shareholders are almost always going to lose when dealing with shareholders, because for every share issued has one vote.

The results of this research showed Capital Markets Law and BAPEPAM regulation Number IX.G.1 About Merger or Consolidation Enterprises Public Company or the Issuer does not regulate further the understanding and clear criteria of "reasonable stock price". But in bank merger the form of public company, necessary services as a professional independent appraisal supporting the capital markets as mentioned in Article 64 and Article 67 of Act Number 8 Year 1995 About Capital Market, which in turn can make a reasonable assessment of the stock price that reflects fairness for public or minority shareholders.
\end{abstract}

Key Words : Bank mergers, Legal protection, Public shareholders

\section{PENDAHULUAN}

\section{Latar Belakang}

Bagi masyarakat pada era globalisasi seperti sekarang ini, mendengar kata bank merupakan hal yang tidak asing lagi, melainkan bank sudah merupakan mitra dalam memenuhi semua kebutuhan keuangan mereka. Secara sederhana bank diartikan sebagai lembaga keuangan yang kegiatan usahanya adalah menghimpun dana dari masyarakat dan menyalurkan kembali dana itu ke masyarakat, serta memberikan jasa-jasa bank lainnya. ${ }^{1}$

$$
\text { Bank adalah bagian dari sistem }
$$
keuangan dan sistem pembayaran suatu negara, bahkan di era globalisasi sekarang ini, bank juga telah menjadi bagian dari sistem pembayaran dunia. ${ }^{2}$ Dalam dunia

\footnotetext{
${ }^{1}$ Kasmir, 2003, Dasar-dasar Perbankan, PT. Raja Grafindo Persada, Jakarta (Selanjutnya ditulis Kasmir 1), . h. 2.

${ }^{2}$ Adrian Sutedi, 2008, Hukum Perbankan Suatu Tinjauan Pencucian Uang, Merger,
} 
modern sekarang ini, peranan perbankan dalam hal memajukan perekonomian suatu negara sangatlah besar karena hampir semua sektor yang berhubungan dengan berbagai kegiatan keuangan selalu membutuhkan jasa bank. Anggapan ini tentunya tidak salah, karena fungsi bank sebagai lembaga keuangan sangatlah vital, misalnya dalam hal penciptaan uang, mengedarkan uang, menyediakan uang untuk menunjang kegiatan usaha, tempat mengamankan uang, tempat melakukan investasi dan jasa keuangan lainnya.

Krisis ekonomi dan moneter yang terjadi di Indonesia pada tahun 1997, merupakan pukulan yang sangat berat bagi sistem perekonomian Indonesia. Pada periode tersebut banyak lembaga-lembaga keuangan yang mengalami kesulitan keuangan dan membawa dampak pada ambruknya perekonomian bangsa Indonesia, termasuk sektor Perbankan Nasional. Hal ini ditandai dengan bangkrutnya bank-bank konvensional dengan dilikuidasinya puluhan bank dan beberapa bank masuk dalam pengawasan Badan Penyehatan Perbankan Nasional.

Pada tanggal 5 Oktober 2006, Bank Indonesia menerbitkan kebijakan mengenai Kepemilikan Tunggal Perbankan (Single Presence Policy) yang

Likuidasi, dan Kepailitan, Cetakan II, Sinar Grafika, Jakarta, h.1. tertuang dalam Peraturan Bank Indonesia Nomor 8/16/PBI/2006. Ketentuan mengenai kepemilikan tunggal perbankan ini menetapkan bahwa setiap pihak baik perorangan maupun korporasi hanya boleh menjadi pemegang saham pengendali pada satu bank. Tujuan diterbitkannya Kebijakan kepemilikan tunggal perbankan ini antara lain untuk meningkatkan pengawasan terhadap bank-bank di Indonesia dan juga sebagai salah satu prasyarat untuk mewujudkan struktur Perbankan Indonesia yang sehat dan kuat.. Kebijakan kepemilikan tunggal perbankan ini tentunya berimplikasi pada pihak-pihak yang sudah menjadi pemegang saham pengendali di dua atau lebih bank. Untuk itu kepada mereka diberikan tiga pilihan. Pertama, melepas kepemilikannya sehingga hanya menjadi pemegang saham pengendali pada satu bank. Kedua, menggabungkan (merger) bank yang dimiliki. Ketiga, pembentukan perseroan induk dibidang perbankan (bank holding company). ${ }^{3}$

Pemilihan merger sebagai salah satu usaha penyelamatan bank memiliki daya magnet yang cukup kuat dalam lingkaran dunia usaha yang melibatkan banyak aspek

\footnotetext{
${ }^{3}$ Sitompul, Zulkarnain, "Merger, Akuisisi dan Konsolidasi Perbankan Relevansinya dengan Kebijakan Single Presence Policy", dalam http:/hukum perbankan. blogspot. Com /search /label/akuisisi, Diakses pada tanggal 20 April 2011.
} 
diantaranya aspek hukum yang mengiringi proses merger dari awal hingga akhir proses. Pengaturan mengenai merger bank diatur dalam Peraturan Pemerintah No. 28 Tahun 1999 Tentang Merger, Konsolidasi dan Akuisisi Bank, Bagi Bank yang berbentuk perseroan terbuka harus memperhatikan Peraturan BAPEPAM No. IX.G.1 tentang Penggabungan Usaha atau Peleburan Usaha Perusahaan Publik atau Emiten. Disamping peraturan tersebut, tindakan merger bank juga harus memperhatikan Undang-Undang Perseroan Terbatas, Undang-Undang Perbankan dan Undang-Undang Pasar Modal.

Merger merupakan suatu perbuatan hukum, tentu saja tidak hanya melahirkan konsekuensi ekonomis dan finansial melainkan juga konsekuensi yuridis. Konsekuensi merger yang perlu dicermati adalah dampak terhadap pemegang saham khususnya pemegang saham publik pada bank yang berbentuk perseroan terbuka. Pada umumnya pemegang saham publik merupakan investor yang melakukan investasi saham untuk memperoleh keuntungan berupa deviden dan keuntungan dari selisih harga jual dan harga beli saham (capital gain). Pemegang saham publik seringkali dipersepsikan sebagai pemegang saham minoritas pada suatu perseroan terbuka, hal ini berdasarkan asumsi bahwa pada umumnya perseroan terbuka melepas atau menjual sahamnya kepada masyarakat luas/publik dengan jumlah yang kecil antara 15 persen hingga 25 persen. ${ }^{4}$

Dalam hal terjadinya merger posisi atau kedudukan pemegang saham publik atau minoritas sangat lemah berkaitan dengan pengambilan keputusan untuk menyetujui rancangan penggabungan perseroan dalam Rapat Umum Pemegang Saham (RUPS). Jika dilihat dari kepemilikan saham, pemegang saham publik atau minoritas umumnya selalu akan kalah bila berhadapan dengan pemegang saham mayoritas. Hal ini disebabkan karena dalam setiap saham yang dikeluarkan mempunyai satu hak suara. Oleh karena itu, mau tidak mau pemegang saham publik atau minoritas harus mengikuti suara mayoritas yang menyetujui rancangan penggabungan perseroan tersebut. Bagi pemegang saham publik atau minoritas yang tidak menyetujui rancangan penggabungan perseroan, hanya dapat menggunakan hak untuk menjual sahamnya dengan harga yang wajar sesuai dengan ketentuan Pasal 6 Peraturan Pemerintah No. 28 Tahun 1999 Tentang Merger, Konsolidasi dan Akuisisi Bank. Namun, kriteria mengenai harga saham wajar tersebut tidak

4“"Komisaris $\begin{gathered}\text { Independen" dalam } \\ \text { http://economy.okezone.com/read/2012/07/22/226/ }\end{gathered}$
666820/komisaris-independen. Diakses tanggal 10
Desember 2012.


dijelaskan lebih lanjut dalam peraturan tersebut, sehingga hal ini dapat menimbulkan interpretasi yang bermacammacam dan kemungkinan bisa menimbulkan kerugian terhadap pemegang saham publik atau minoritas.

\section{Rumusan masalah}

Berdasarkan pada latar belakang masalah yang diuraikaan diatas, maka permasalahan yang dibahas dalam penulisan ini adalah : Bagaimanakah pengaturan mengenai harga saham wajar sebagai bentuk perlindungan hukum terhadap pemegang saham publik dalam merger bank yang berbentuk perseroan terbuka?.

\section{Tujuan Penulisan}

Tujuan dilakukannya penulisan ini adalah untuk mengetahui mengenai pelaksanaan merger bank di Indonesia serta untuk mengetahui permasalahanpermasalahan hukum yang ditimbulkan dari adanya tindakan merger. Disamping itu penulisan ini secara khusus bertujuan untuk mengetahui pengaturan harga saham wajar sebagai bentuk perlindungan hukum terhadap pemegang saham publik dalam pelaksanaan merger bank yang berbentuk perseroan terbuka, berdasarkan pada peraturan perundang-undangan yang mengatur tentang merger.

\section{METODE PENELITIAN}

Penelitian ini merupakan jenis penelitian hukum normatif yang bersifat deskriptif analitis. Penelitian ini dalam pembahasan masalahnya menggunakan pendekatan perundang-undangan yang sumber bahan hukumnya diperoleh dari hasil penelitian kepustakaan terhadap bahan-bahan hukum yang bersumber pada peraturan perundang-undangan mengenai merger, literatur-literatur yang terkait dengan permasalahan yang dibahas serta dokumen-dokumen merger bank.

\section{HASIL DAN PEMBAHASAN}

Dasar hukum dari suatu perusahaan terbuka yang melakukan merger tentu berlaku Undang-Undang No. 8 Tahun 1995 tentang Pasar Modal dan Peraturan BAPEPAM No. IX.G.1 tentang Penggabungan Usaha atau Peleburan Usaha Perusahaan Publik atau Emiten. Akan tetapi, di lain pihak sebagai suatu Perseroan terbatas, kecuali diatur lain dalam perundang-undangan di bidang Pasar Modal, maka dalam melakukan setiap kegiatan termasuk merger, perseroan terbatas tersebut wajib mengikuti ketentuan dalam UndangUndang Perseroan Terbatas dan peraturan pelaksananya. ${ }^{5}$ Pasal 84 Undang-Undang

\footnotetext{
${ }^{5}$ Munir Fuady, 2008, Hukum Tentang Merger, PT. Citra Aditya Bakti, Bandung (Selanjutnya disebut Munir Fuady 1), h. 145.
} 
No. 8 Tahun 1995 Tentang Pasar Modal menyebutkan bahwa :

"Emiten atau Perusahaan Publik yang melakukan penggabungan, peleburan, atau pengambilalihan perusahaan lain wajib mengikuti ketentuan mengenai keterbukaan, kewajaran, dan pelaporan yang ditetapkan oleh Bapepam dan peraturan perundang-undangan lainnya yang berlaku".

Jika melihat bunyi ketentuan pasal 84 Undang-Undang Pasar Modal tersebut, maka Emiten atau Perusahaan Publik yang melakukan merger/penggabungan juga wajib mengikuti ketentuan UndangUndang Perseroan Terbatas dan peraturan pelaksananya termasuk Peraturan Pemerintah No. 28 Tahun 1999 Tentang Merger, Konsolidasi, dan Akuisisi Bank.

Persyaratan untuk melakukan merger bank yang berbentuk perseroan terbuka tertuang dalam ketentuan Angka 3.a Peraturan BAPEPAM No. IX.G.1 Tentang Penggabungan Usaha atau Peleburan Usaha Perusahaan Publik atau

Emiten. Dalam ketentuan peraturan tersebut, terdapat empat persyaratan utama yang harus dipenuhi oleh Emiten / Perusahaan Publik dalam hal akan melakukan tindakan merger tersebut. Pertama, direksi dan komisaris perusahaan-perusahaan yang akan merger wajib membuat pernyataan bahwa kegiatan penggabungan usaha atau peleburan usaha dilakukan dengan memperhatikan kepentingan perseroan, pemegang saham, persaingan usaha yang sehat, pemegang saham publik dan karyawan. Kedua, pernyataan tersebut harus didukung oleh pihak independen. Ketiga, Emiten/ Perusahaan Publik wajib menyampaikan pernyataan penggabungan usaha atau peleburan usaha yang berisi rancangan penggabungan usaha / peleburan usaha. Keempat, memperoleh persetujuan rapat umum pemegang saham Emiten / Perusahaan Publik.

Akibat hukum merger bank bagi pemegang saham adalah bahwa seluruh pemegang saham bank yang melakukan merger akan menjadi pemegang saham bank hasil merger kecuali terdapat pemegang saham yang tidak menyetujui merger. Hal ini tertuang dalam pasal 2 ayat (1) Peraturan Pemerintah No. 28 Tahun 1999 yang menyebutkan bahwa :

"Pemegang saham Bank yang melakukan Merger atau Konsolidasi menjadi pemegang saham Bank hasil Merger atau Bank hasil Konsolidasi”.

Bagi pemegang saham publik atau minoritas yang tidak setuju dengan tindakan merger, walaupun RUPS dengan suara mayoritas tertentu telah memutuskan untuk merger, kepada pihak yang kalah suara ini oleh hukum diberikan perlindungan yaitu adanya suatu hak khusus yang disebut dengan appraisal right. Appraisal rights adalah hak dari pemegang saham publik atau minoritas 
yang tidak setuju terhadap merger bank (kalah suara) atau terhadap tindakantindakan korporat lainnya, untuk menjual saham yang dipegangnya itu kepada perseroan yang bersangkutan, dimana pihak perseroan yang mengisukan saham tersebut wajib membeli kembali sahamsahamnya dengan harga yang pantas. ${ }^{6}$

Dalam Peraturan BAPEPAM No. IX.G.1 Tentang Penggabungan Usaha atau Peleburan Usaha Perusahaan Publik atau Emiten tidak mengatur mengenai appraisal right, namun pengaturan mengenai appraisal rights tertuang dalam ketentuan Pasal 62 Ayat (1) UndangUndang Nomor 40 Tahun 2007 Tentang Perseroan Terbatas yang menyebutkan bahwa :

"Setiap pemegang saham berhak meminta kepada Perseroan agar sahamnya dibeli dengan harga yang wajar apabila yang bersangkutan tidak menyetujui tindakan Perseroan yang merugikan pemegang saham atau Perseroan berupa :

a. Perubahan anggaran dasar;

b. Pengalihan atau penjaminan kekayaan Perseroan yang mempunyai nilai lebih dari $50 \%$ (lima puluh persen) kekayaan bersih Perseroan; atau

c. Penggabungan, Peleburan, Pengambilalihan, atau Pemisahan “.

Berdasarkan Pasal 62 Ayat (1) Undang-Undang Perseroan Terbatas tersebut, maka dapat dijelaskan bahwa

\footnotetext{
${ }^{6}$ Adrian Sutedi, Op.Cit, h.118.
}

Hak appraisal adalah hak dari setiap pemegang saham untuk menjual sahamnya kepada perseroan, dimana harga saham yang dibeli oleh perseroan haruslah harga yang wajar. Hak appraisal tersebut baru ada jika perseroan melakukan tindakan korporat tertentu yang dapat merugikan kepentingan pemegang saham, tindakantindakan perseroan tersebut antara lain :

1. Perubahan anggaran dasar;

2. Penjualan, penjaminan, pertukaran sebagian besar atau seluruh kekayaan perseroan; atau

3. Penggabungan, peleburan, atau pengambilalihan perseroan.

Selanjutnya dalam Pasal 126 Ayat (3) Undang-Undang Perseroan Terbatas Pelaksanaan hak appraisal tersebut tidak menyebabkan berhentinya proses penggabungan,peleburan, pengambilalihan atau pemisahan. Berdasarkan Pasal 126 Ayat (3) tersebut, maka pihak pemegang saham publik atau minoritas tidak dapat menghentikan proses merger. Yang menjadi persoalan dalam hal ini adalah Undang-Undang Perseroan Terbatas tidak menjelaskan lebih lanjut mengenai apa yang dimaksud dengan harga saham yang wajar dan bagaimana kriteria harga saham wajar tersebut, sehingga hal ini merupakan kelemahan yang dapat dimanfaatkan oleh pemegang saham mayoritas dalam menentukan harga saham yang wajar tersebut dalam RUPS yang nantinya dapat 
menyebabkan kerugian bagi pemegang saham publik atau minoritas. Kelemahankelemahan tersebut dapat terlihat dari : ${ }^{7}$

1. Pihak perseroan yang dikontrol oleh pemegang saham mayoritas cenderung untuk melakukan merger pada saat harga saham terendah, sehingga tidak diperlukan biaya yang banyak untuk membeli saham-saham dari pemegang saham minoritas;

2. Pihak yang dikontrol oleh pemegang saham mayoritas dapat mempermainkan informasi dalam hubungan dengan tindakan perseroan terbatas yang akan dilakukannya untuk menekan harga saham di pasar. Hal ini dikarenakan pihak pemegang saham mayoritas menguasai informasi lebih banyak dari pemegang saham minoritas, sehingga setiap saat pihak mayoritas dapat berlaku curang dengan informasi yang di miliki;

3. Turun naik harga saham di pasar relatif besar tanpa arah yang pasti, sehingga tidak ada jaminan bahwa harga saham saat itu mencerminkan harga saham yang sebenarnya.

Bagi perseroan terbatas yang telah go public, dalam hukum pasar modal mengatur tentang ketentuan pembelian kembali yaitu dalam Peraturan Bapepam

7 Munir Fuady, 2005, Perlindungan Pemegang Saham Minoritas, CV Utomo, Bandung (Selanjutnya disebut Munir Fuady 2), h.187.
No.IX.B.2 tentang Pembelian Kembali Saham yang Dikeluarkan oleh Emiten atau Perseroan Publik. Pada peraturan ini menjelaskan antara lain: ${ }^{8}$

1. RUPS dilarang mendelegasikan kewenangan untuk membeli kembali saham kepada direksi atau komisaris dalam jangka waktu lebih dari 18 (delapan belas bulan).

2. Emiten atau perseroan publik wajib mengungkapkan rencana pembelian kembali saham kepada seluruh pemegang saham sekurang-kurangnya 28 (dua puluh delapan) hari sebelum RUPS. Rencana pembelian kembali saham wajib memuat informasi sebagai berikut :

a) Perkiraan jadwal dan biaya pembelian kembali saham tersebut;

b) Perkiraan menurunnya pendapatan emiten atau perseroan publik sebagai akibat pelaksanaan pembelian kembali saham dan dampak atas biaya pembiayaan emiten atau perseroan publik;

c) Performa laba per saham emiten atau perseroan publik setelah rencana pembelian kembali saham dilaksanakan, dengan

\footnotetext{
8 Hendy M.Fakhruddin, Go Public Strategi Pendanaan dan Peningkatan Nilai Perseroan, 2008, PT. Elex Media Komputindo, Jakarta, h. 240.
} 
mempertimbangkan menurunnya pendapatan;

d) Pembatasan harga saham untuk pembelian kembali saham;

e) Pembatasan jangka waktu pembelian kembali saham;

f) Metode yang akan digunakan untuk membeli kembali saham;

g) Pembahasan dan analisis manajemen mengenai pengaruh pembelian kembali saham terhadap kegiatan usaha dan pertumbuhan emiten atau perseroan publik di masa yang akan datang.

Peraturan hukum pasar modal dalam

Peraturan Bapepam IX.B.2 mengenai pembelian saham kembali mensyaratkan metode yang akan digunakan dalam membeli kembali saham, tetapi juga mengandung kelemahan yaitu apakah metode yang digunakan tersebut telah memenuhi hak dari pemegang saham publik atau minoritas untuk mendapatkan sahamnya dibeli dengan harga yang wajar. Tidak ada ketentuan yang jelas mengenai harga saham yang wajar, hal ini dapat menimbulkan interpretasi yang bermacammacam dan kemungkinan bisa menimbulkan kerugian terhadap pemegang saham minoritas seperti yang telah disebutkan diatas.

Dalam rancangan penggabungan PT Bank Niaga Tbk. dengan PT Bank Lippo Tbk. mengenai pembelian kembali saham dari pemegang saham publik yang tidak menyetujui rencana merger menentukan bahwa harga pembelian yang akan dibayarkan oleh CIMB Group adalah Rp.1.052 untuk saham publik Bank Niaga dan Rp.2.969 untuk saham publik Bank Lippo. ${ }^{9}$ Harga tersebut diperoleh dari metode penilaian yang dilakukan oleh PT Ujatek Baru yang ditunjuk sebagai penilai independen oleh Bank Peserta Penggabungan.

Perseroan penilai (PT Ujatek Baru) merupakan pihak professional yang harus dilibatkan dalam transaksi merger khususnya pada transaksi merger perseroan terbuka. Dalam proses merger perseroan terbuka, perseroan-perseroan yang akan melakukan merger harus mencapai kesepakatan tentang pihak professional yang akan ditunjuk dan dilibatkan serta memberikan produk jasanya dalam rangka transaksi merger tersebut. Pihak-pihak profesional tersebut antara lain Akuntan, Konsultan Hukum, Perusahaan Penilai, Notaris, Konsultan Pajak, dan Penasihat Keuangan. Perlunya partisipasi para pihak profesional tersebut disebabkan karena transaksi merger tidak terlepas dari proses negosiasi dimana proses negosiasi tersebut membutuhkan

\footnotetext{
${ }^{9}$ Rancangan Penggabungan PT. Bank Niaga Tbk. Dengan PT. Bank Lippo, 3 Juni 2008, h.74.
} 
suatu perpaduan keahlian dan pendapat beberapa disiplin profesi. ${ }^{10}$

Perseroan penilai merupakan profesi penunjang pasar modal, hal ini diatur dalam ketentuan Pasal 64 Ayat (1) Undang-Undang No. 8 Tentang Pasar Modal yang menyebutkan bahwa :

"Profesi Penunjang Pasar Modal terdiri dari : a. Akuntan; b. Konsultan Hukum, c. Penilai; d. Notaris; e. Profesi lain yang ditetapkan dengan Peraturan Pemerintah “.

Selanjutnya menurut Pasal 64 Ayat (2) Undang-Undang Pasar Modal, Profesi Penunjang Pasar Modal wajib terdaftar di Badan Pengawas Pasar Modal (Bapepam) untuk dapat melakukan kegiatan di bidang Pasar Modal. Kegiatan usaha jasa penilaian diatur secara khusus dalam Keputusan Menteri Perindustrian dan Perdagangan Republik Indonesia Nomor 549/MPP/Kep/VIII/2002 tanggal 16 Agustus 2002 tentang Ketentuan Perizinan Usaha Jasa Penilaian. Menurut Pasal 3 Ayat (2) Keputusan Menteri Perindustrian dan Perdagangan tersebut, Perseroan Jasa Penilaian merupakan perseroan yang melakukan kegiatan usaha jasa penilaian harus berbadan hukum Indonesia dan dalam bentuk perseroan terbatas. Perseroan jasa penilaian memiliki ruang

${ }^{10}$ Cornelius Simanjuntak, 2004, Hukum Merger Perseroan Terbatas; Teori dan Praktek, PT. Citra Aditya Bakti, Bandung, h. 55. lingkup kegiatan usaha jasa penilaian sebagai berikut $:^{11}$

1. Penilaian untuk menentukan nilai ekonomis terhadap harta benda berwujud maupun yang tidak berwujud, yaitu penilaian Aktiva Tetap dan Penilaian Usaha ;

2. Penilaian Proyek ;

3. Penilaian Kelayakan Teknis ;

4. Penilaian dan Konsultasi Pengembangan termasuk Studi Kelayakan Proyek;

5. Penilaian dan pengawasan proyek;

6. Penilaian dan konsultasi investasi;

7. Penilaian dan Teknologi Informasi di Bidang Properti;

8. Penilaian Konsultasi Properti termasuk kegiatan konsultasi keuangan properti; dan

9. Pengelolaan Harta Benda.

PT Ujatek Baru selaku penilai independen yang ditunjuk dalam merger PT Bank Niaga Tbk. dan PT Bank Lippo Tbk telah melakukan analisa dan penilaian atas saham (ekuitas) Bank Niaga dan LB sesuai dengan Standard Penilai Indonesia (SPI) yaitu dengan menggunakan 3 (tiga) metode penilaian di bawah ini: ${ }^{12}$

1. Metode Arus Kas yang Didiskonto (Discounted Cash Flow Method)

\footnotetext{
${ }^{11}$ Ibid.

${ }^{12}$ Rancangan Penggabungan PT. Bank Niaga Tbk. Dengan PT. Bank Lippo, Op. Cit, h. 60.
} 
2. Model Dividen yang Didiskonto (Dividend Discount Model)

3. Metode Penyesuaian Nilai Buku (Adjusted Book Value)

Dengan metode dan prosedur yang dilakukan oleh PT Ujatek Baru, diperoleh hasil penilaian atas nilai intrinsik wajar dari masing-masing Bank Peserta Penggabungan yang ternyata memberikan premium atas harga perdagangan secara historis. Kepada seluruh pemegang saham publik dari Bank Peserta Penggabungan baik yang setuju maupun tidak menyetujui rancana penggabungan diberikan kesempatan untuk menjual saham yang dimilikinya dengan harga berdasarkan hasil penilaian usaha diatas.

Penunjukkan PT Ujatek Baru sebagai penilai independen sehubungan dengan kewajaran nilai saham pada penggabungan PT Bank Niaga Tbk dengan PT Bank Lippo Tbk dapat dibenarkan, karena PT Ujatek Baru adalah perseroan penilai yang merupakan Profesi Penunjang Pasar Modal dan sudah terdaftar pada Badan Pengawas Pasar Modal sesuai dengan ketentuan Pasal 64 Ayat (1) dan Ayat (2) Undang-Undang No. 8 Tahun 1995 Tentang Pasar Modal.

\section{SIMPULAN DAN SARAN}

\section{Simpulan}

Undang-Undang Pasar Modal dan Peraturan BAPEPAM No. IX.G.1
Tentang Penggabungan Usaha atau Peleburan Usaha Perusahaan Publik atau Emiten tidak mengatur lebih lanjut mengenai pengertian dan kriteria jelas mengenai "harga saham yang wajar" sebagai bentuk perlindungan hukum terhadap pemegang saham publik. Hal ini juga tidak diatur dalam UndangUndang Perseroan Terbatas serta peraturan pelaksananya, sehingga dapat menimbulkan interpretasi yang bermacam-macam dan kemungkinan bisa menimbulkan kerugian terhadap pemegang saham publik atau minoritas. Namun dalam merger bank yang berbentuk perseroan terbuka diperlukan jasa penilai independen sebagai profesi penunjang pasar modal sebagaimana disebutkan dalam Pasal 64 dan Pasal 67 Undang-Undang No. 8 Tahun 1995 Tentang Pasar Modal, yang nantinya dapat melakukan penilaian terhadap harga saham wajar yang mencerminkan keadilan bagi pemegang saham publik atau minoritas.

\section{Saran}

Dalam rangka pelaksanaan merger perseroan terbuka hendaknya UndangUndang Pasar Modal, Peraturan BAPEPAM serta Peraturan perundangundangan lainnya tentang merger, mengatur secara lebih jelas ketentuan mengenai harga saham wajar sebagai 
bentuk perlindungan hukum terhadap pemegang saham publik, sehingga apa yang diatur dalam Undang-Undang Perseroan Terbatas dan peraturan pelaksananya menjamin kepastian hukum bagi pemegang saham publik atau minoritas.

\section{DAFTAR PUSTAKA}

Fakhruddin,Hendy M., Go Public Strategi Pendanaan dan Peningkatan Nilai Perseroan, 2008, PT. Elex Media Komputindo, Jakarta.

Fuady, Munir, 2005, Perlindungan Pemegang Saham Minoritas, CV Utomo, Bandung. 2008, Hukum Tentang Merger, PT. Citra AdityaBakti, Bandung.

Kasmir, 2003, Dasar-dasar Perbankan, PT. Raja Grafindo Persada, Jakarta. "Komisaris Independen" dalam http://economy.okezone.com/read/ 2012/07/22/226/666820/

komisaris-independen., Diakses tanggal 10 Desember 2012.

Rancangan Penggabungan PT. Bank Niaga Tbk. Dengan PT. Bank Lippo, 3 Juni 2008.
Sitompul, Zulkarnain, "Merger, Akuisisi dan Konsolidasi Perbankan Relevansinya dengan Kebijakan Single Presence Policy”, dalam http:/hukum perbankan. blogspot. Com /search /label/akuisisi, Diakses pada tanggal 20 April 2011.

Sutedi, Adrian, 2008, Hukum Perbankan Suatu Tinjauan Pencucian Uang, Merger, Likuidasi, dan Kepailitan, Cetakan II, Sinar Grafika, Jakarta.

Simanjuntak, Cornelius 2004, Hukum Merger Perseroan Terbatas; Teori dan Praktek, PT. Citra Aditya Bakti, Bandung.

Yoserwan, 2006, Hukum Ekonomi Indonesia dalam Era Reformasi dan Globalisasi, Andalas University Press, Padang.

Biodata Penulis :

Nama : Pande Yogantara S.

Alamat : Jl. A.Yani Gg. Jatayu No.7 Denpasar

No. Telp : : 089685534544

E-mail : pande_maplo@yahoo.co.id 